\title{
Effects of Incision, Forced-air Drying, and Pressure Pretreatments on Wet Pockets, Drying Rate, and Drying Defects of Acacia mangium Wood
}

\begin{abstract}
Elia Ambrose, ${ }^{\mathrm{a}}$ Ismail Jusoh, ${ }^{\mathrm{a}, *}$ Alik Duju, ${ }^{\mathrm{b}}$ and Norsyarina Welman ${ }^{\mathrm{b}}$
The pretreatment of 7- and 10-year-old Acacia mangium wood using incision, forced-air dying, and pressure were conducted to evaluate the effects on wet pockets, the drying rate, and drying defects. Quarter and rift sawn boards were used in this study. Results showed that the incidence of wet pockets in the incised, forced-air drying, and pressure-treated quarter and rift sawn boards of 7-year-old $A$. mangium alleviated up to $35 \%$ and $79 \%, 60 \%$ and $54 \%$, and $54 \%$ and $82 \%$, respectively. In 10 -yearold $A$. mangium, the occurrence of wet pockets was reduced by $68 \%$ and $60 \%, 31 \%$ and $73 \%$ and $82 \%$ and $73 \%$ in quarter and rift sawn boards, respectively. Drying rates of 7 -year-old $A$. mangium pressure-treated boards increased by $5 \%$ and $40 \%$ in quarter and rift sawn boards, respectively. The drying rate was $10 \%$ faster for 10 -year-old $A$. mangium pressure-treated boards. The application of the pressure pretreatment yielded no severe drying defects at the end of the drying period, except for a mild collapse in one of the 10-years old $A$. mangium sample boards. Incision and forced-air drying pretreatments improved the drying rate; however, pressure treatment was found to be superior in reducing wet pockets and drying defects.
\end{abstract}

DOI: 10.15376/biores.17.1.1643-1658

Keywords: Acacia mangium; Pretreatment; Drying rate; Wet pockets; Drying defects

Contact information: a: Faculty of Resource Science and Technology, Universiti Malaysia Sarawak, Kota Samarahan, Sarawak 94300 Malaysia; b: Applied Forest Science and Industry Development, Sarawak Forestry Corporation, Kuching, Sarawak 93250 Malaysia; *Corresponding author: jismail@ unimas.my

\section{INTRODUCTION}

Acacia mangium can be the primary timber source for local wood-based industries, especially for furniture, owing to its delicate appearance, grain orientation, and colour, which increase the aesthetic value of the wood. Apart from that, the quality, strength, and durability of $A$. mangium wood will bring many advantages to local wood-based industries if this wood can be utilized and managed appropriately. However, kiln-dried A. mangium wood has an uneven distribution of moisture contents (MC), which is a problem. The primary issue regarding the uneven drying of A. mangium wood is the presence of wet pockets. In timber drying, wet pockets typically occur in quarter sawn, radial-sawn, rift sawn, and double rift sawn boards and are seldom found in flat-sawn or tangential boards (Tenorio and Moya 2011; Gan et al. 2015).

Wet pockets, sometimes referred to as wet wood or wet spots, are abnormal zones in the heartwood with high moisture content. They occur in both softwood and hardwood. One primary characteristic of wet wood is that it dries so slowly that it is still wet when normal wood is dry. This causes variability in the final moisture content and fails to meet 
requirements. The moisture content of wet pockets in A. mangium ranges from $12 \%$ to $76 \%$ and averages at $25 \%$ (Tenorio et al. 2012). It is also likely that these areas will collapse, split, or check during drying.

Most timber and lumber needs to be adequately dried to achieve a suitable quality and degree of production. As such, drying is a fundamental process in manufacturing wood. The wood drying process influences the final quality of the wood product. Dried timber needs to be defect-free, especially from honeycombing and severe surface and end checks. The dried wood must have an even final moisture content distribution to ensure dimensional stability. Uneven distribution of the final moisture content affects the quality and value of the dried timber (Elustondo et al. 2010).

Acacia mangium is a popular reforestation plantation tree species planted in Sarawak and throughout Asia. It has a fast growth rate, excellent wood quality, an attractive wood appearance, and tolerance to various environmental conditions (Tenorio and Moya 2011). However, A. mangium faces several drying setbacks, e.g., the uneven distribution of final moisture contents, drying defects, and the presence of wet pockets at the end of drying. The occurrence of wet pockets causes dimensional instability in A. mangium. This will restrict the end uses of $A$. mangium wood, especially indoor joinery and the furniture industry applications.

Several pretreatments and methods have reportedly alleviated wet pockets and the variation in final moisture contents. Applying a hot water bath and microwave pretreatment on A. mangium boards before kiln drying can reduce the occurrence of the wet pockets developed after the kiln drying process (Dashti et al. 2012; Gan et al. 2015). Microexplosion pretreatment improved the drying rate in poplar wood (Ma et al. 2015). Gunzerodt et al. (1986) introduced the wood compression method for wood treatment and preservation by improving the rate of wood drying. They applied the rolling compression method to the wood and reported that the compression method was able to enhance the permeability of the wood and the rate of the wood drying. Another wood compression method was also studied by Zhao et al. (2015), who applied radial and tangential compression on the wood prior to drying. They reported that the method yielded good results. The drying rate was increased due to the rupture of the pits in the wood.

Pretreatments of green eucalyptus by pre-heating, pre-steaming, microwave, prefreezing, and boiling wood improved wood permeability, drying rate and reduced collapse during drying (Yang and Liu 2018). Chai et al. (2019) reported that pretreating Mongolian pine with wet air and steaming prior to high-frequency vacuum drying improved drying rate, even moisture distribution and minimized drying defects. Microwave pretreatment before conventional drying improved permeability and decreased the drying time of Chinese fir wood (Weng et al. 2021). Drying juvenile Eucalyptus nitens wood using radiofrequency vacuum without any pretreatment was shown to reduce surface checking and collapse (Ananías et al. 2020).

Very few studies (Dashti et al. 2012; Gan et al. 2015) have been done regarding the pretreatments of timber before drying it to alleviate the occurrence of wet pockets in $A$. mangium wood. The objectives of this study were to determine the effects of incision, forced-air drying, and pressure pretreatments on the occurrence of wet pockets, the drying rate, and drying defects in A. mangium dried timber. This study experimented with quarter and rift sawn A. mangium boards because they can develop wet pockets during drying. The information obtained from this study will establish a promising pretreatment method that can be applied to A. mangium timber before being dried. 


\section{EXPERIMENTAL}

\section{Sample Preparation}

A total of 15 healthy and defect-free trees for both 7- and 10-year-old A. mangium were harvested from a forest plantation near Bintulu, Sarawak, Malaysia, with diameters at breast height $(\mathrm{DBH})$ ranging from $22 \mathrm{~cm}$ to $32 \mathrm{~cm}$. A section (billet) of $1 \mathrm{~m}$ long from the stump to DBH was removed from each log. From the DBH point, a clear bole of $5 \mathrm{~m}$ length was bucked from each tree. This study only utilized the first $5 \mathrm{~m}$ bole. The boles were sawn according to the "through to through" log sawing pattern (as shown in Fig. 1) with a target thickness of $30 \mathrm{~mm}$. Quarter and rift sawn boards were selected for the study and processed into a standard size of $27 \mathrm{~mm}$ (thickness) x $150 \mathrm{~mm}$ (width) x $690 \mathrm{~mm}$ (length) (as shown in Fig. 2). This study did not include flat sawn boards because wet pockets rarely occur in tangential or flat-sawn boards (Moya and Muñoz 2008; Gan and Zairul 2011b; Tenorio et al. 2012).

Before subsequent pretreatment experiments, each end of the sample boards was coated with bituminous paint. The mean basic wood density (oven-dry weight/green volume) was determined for the 7- and 10-year-old A. mangium samples were 350 $\mathrm{kg} / \mathrm{m}^{3}$ and $538 \mathrm{~kg} / \mathrm{m}^{3}$, respectively.

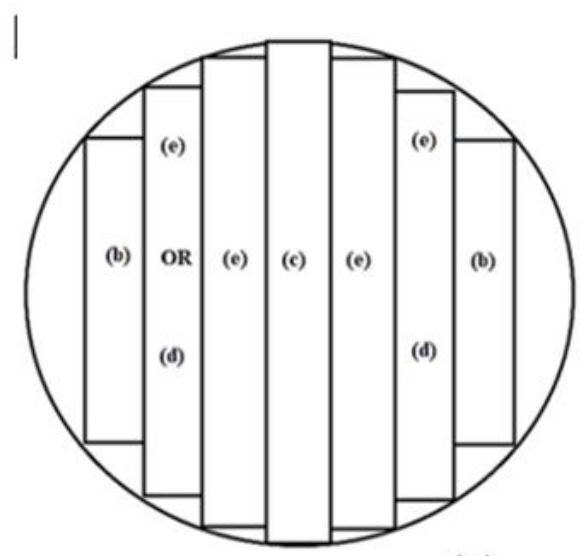

(a) (b)

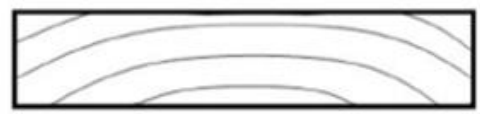

Flat sawn

(c)

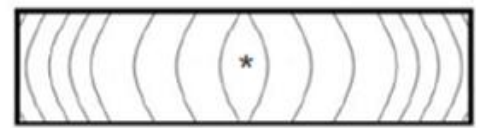

Quarter sawn

(d)

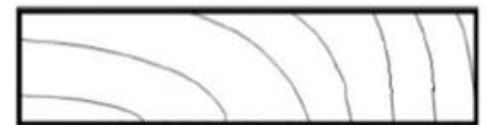

Rift sawn

(e)

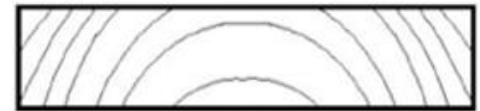

Double rift sawn

Fig. 1. Through and through or plain sawing pattern of the: (a) fresh bole; (b) flat sawn; (c) quarter sawn; (d) rift sawn; and (e) double rift sawn boards

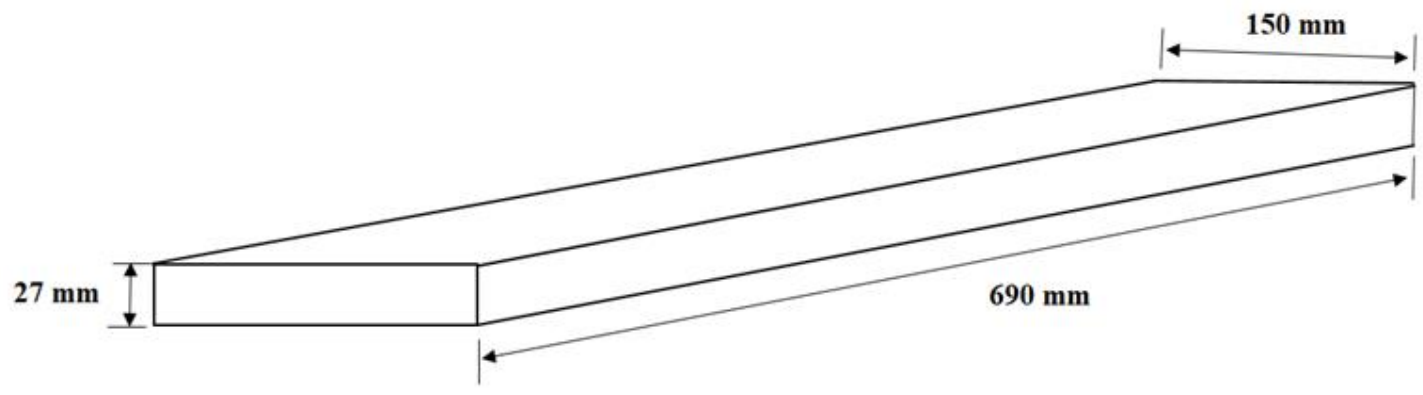

Fig. 2. The standard sample size of the quarter and rift sawn boards 


\section{Pretreatments}

Incision

Incision pretreatment was carried by punching small slits into the surface of the sample boards. The incisions were only made on one surface of the sample boards (Fig. 3). By incising the surface of the boards, it is anticipated to provide passages for moisture movement during wood drying. A Jica Incision Machine was used to incise the sample boards with an incised hole depth of $10 \mathrm{~mm}$.

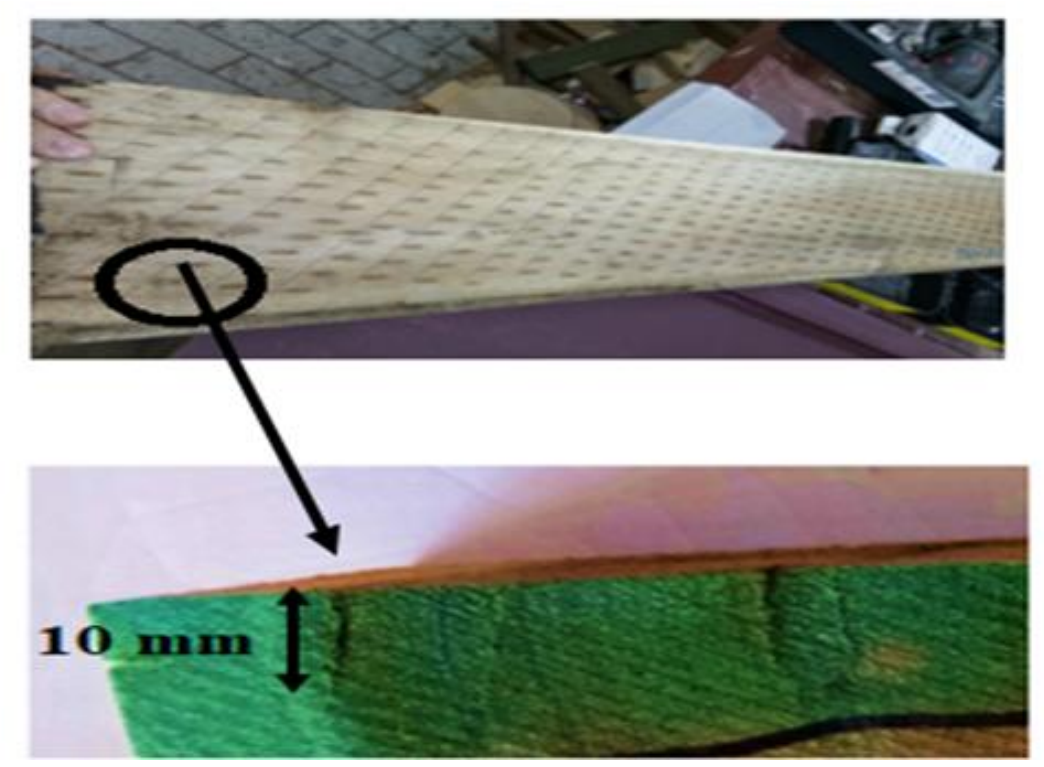

Fig. 3. Incised one side-grain sample board

\section{Forced air-dry}

The sample boards were subjected to forced air drying by using an experimental dryer fan system for a week before drying with an average air velocity of $48 \mathrm{~m} / \mathrm{sec}$. The dry-bulb temperature (DBT) and wet-bulb temperature (WBT) were both set at a temperature of $32{ }^{\circ} \mathrm{C}$.

\section{Pressure}

This pretreatment required the boards to undergo pressure treatment, depicting a full-cell wood treatment process. The sample boards were first placed in a Jica Pressure Treatment steel cylinder, and a vacuum was applied at room temperature for 6 min to remove the air from the cylinder. Then, the pressure was applied without breaking the vacuum until it reached $150 \mathrm{psi}$ and maintained at this pressure for $10 \mathrm{~min}$. Finally, the pressure was released instantaneously.

\section{Wood Drying}

Following the pretreatments, all the sample boards were subjected to drying in a Hilderbrand Experimental Drying Chamber (Hannover, Germany). The drying process was carried out according to the mild drying schedule developed by Tan (2015). As shown in Tables 1 and 2, the mild drying schedules are for 7- and 10-year-old A. mangium boards, respectively. Each batch of drying was comprised of 12 sample boards, with 6 sample boards for quarter and rift sawn boards, respectively. 
Table 1. Mild Drying Schedule for 7-year-old Acacia mangium Wood

\begin{tabular}{|c|c|c|c|c|c|}
\hline $\begin{array}{c}\text { Moisture } \\
\text { Content }(\%)\end{array}$ & $\begin{array}{c}\text { Dry Bulb } \\
\text { Temperature } \\
\left({ }^{\circ} \mathrm{C}\right)\end{array}$ & $\begin{array}{c}\text { Wet Bulb } \\
\text { Depression } \\
\left({ }^{\circ} \mathrm{C}\right)\end{array}$ & $\begin{array}{c}\text { Wet Bulb } \\
\text { Temperature } \\
\left({ }^{\circ} \mathrm{C}\right)\end{array}$ & $\begin{array}{c}\text { Relative } \\
\text { Humidity (\%) }\end{array}$ & $\begin{array}{c}\text { Equilibrium } \\
\text { Moisture } \\
\text { Content }(\%)\end{array}$ \\
\hline$>104$ & 47 & 2.5 & 44.5 & 86 & 17.0 \\
\hline 104 & 47 & 2.8 & 44.2 & 83 & 16.2 \\
\hline 95 & 47 & 3.4 & 43.6 & 82 & 15.1 \\
\hline 85 & 47 & 4.4 & 42.6 & 76 & 13.5 \\
\hline 75 & 47 & 5.6 & 41.4 & 71 & 11.8 \\
\hline 65 & 47 & 7.0 & 40.0 & 63 & 10.5 \\
\hline 55 & 4 & 8.8 & 38.2 & 57 & 9.3 \\
\hline 45 & 47 & 11.0 & 36.0 & 48 & 7.9 \\
\hline 35 & 47 & 13.0 & 34.0 & 42 & 6.8 \\
\hline 30 & 50 & 15.0 & 35.0 & 37 & 6.2 \\
\hline 25 & 57 & 17.0 & 40.0 & 35 & 5.5 \\
\hline 20 & 65 & 18.0 & 47.0 & 35 & 5.4 \\
\hline 15 & 70 & 20.0 & 50.0 & 35 & 4.9 \\
\hline
\end{tabular}

Table 2. Mild Drying Schedule for 10-year-old Acacia mangium Wood

\begin{tabular}{|c|c|c|c|c|c|}
\hline $\begin{array}{c}\text { Moisture } \\
\text { Content }(\%)\end{array}$ & $\begin{array}{c}\text { Dry Bulb } \\
\text { Temperature } \\
\left({ }^{\circ} \mathrm{C}\right)\end{array}$ & $\begin{array}{c}\text { Wet Bulb } \\
\text { Depression } \\
\left({ }^{\circ} \mathrm{C}\right)\end{array}$ & $\begin{array}{c}\text { Wet Bulb } \\
\text { Temperature } \\
\left({ }^{\circ} \mathrm{C}\right)\end{array}$ & $\begin{array}{c}\text { Relative } \\
\text { Humidity }(\%)\end{array}$ & $\begin{array}{c}\text { Equilibrium } \\
\text { Moisture } \\
\text { Content }(\%)\end{array}$ \\
\hline$>107$ & 42 & 1.8 & 40.2 & 90 & 19.0 \\
\hline 107 & 42 & 1.9 & 40.3 & 87 & 18.2 \\
\hline 95 & 42 & 2.7 & 39.3 & 85 & 16.7 \\
\hline 85 & 42 & 3.3 & 38.7 & 76 & 13.7 \\
\hline 75 & 42 & 4.2 & 37.8 & 76 & 13.7 \\
\hline 65 & 42 & 5.0 & 37.0 & 72 & 12.3 \\
\hline 55 & 42 & 5.5 & 36.5 & 69 & 11.8 \\
\hline 45 & 42 & 7.8 & 34.2 & 52 & 8.6 \\
\hline 35 & 42 & 9.5 & 32.5 & 52 & 8.6 \\
\hline 30 & 45 & 10.0 & 35.0 & 49 & 8.2 \\
\hline 25 & 53 & 11.0 & 42.0 & 45 & 7.7 \\
\hline 20 & 61 & 11.8 & 49.2 & 42 & 7.2 \\
\hline 15 & 65 & 12.2 & 52.8 & 41 & 7.0 \\
\hline
\end{tabular}

\section{Determination of the Green and Final Moisture Content}

The initial or green and the final moisture content were determined according to ASTM standard D4442-16 (2016). The formula for determining the moisture content is shown in Eq. 1.

$$
\text { Moisture Content }=\frac{\text { Green (Initial) wt-oven dry wt }}{\text { Oven dry wt }} \times 100 \%
$$

\section{Determination of the Area of a Wet Pocket}

A strip with the dimensions of $20 \mathrm{~mm}$ (length) x $150 \mathrm{~mm}$ (width) $\times 27 \mathrm{~mm}$ (thickness) was extracted from the middle of the dried sample boards. Cobalt chloride was sprayed on the transversal section of the strips. The pinkish-brown region indicated a region with a high moisture content, which indicated a wet pocket region. Boundaries of wet pockets were delineated on the transversal section, and the wet pocket area was 
determined using $2 \mathrm{~cm} \times 2 \mathrm{~cm}$ graph paper and expressed as a per cent of the total area.

\section{Determination of the Drying Rate}

The drying period is the drying duration (in $h$ ) from the start to the termination of the drying process. The rate of drying is the measurement of the efficiency of a drying process. The drying rate was estimated by dividing the average moisture loss $(\%)$ with the drying period, as shown in Eq. 2,

$$
\text { Drying rate }(\% / \mathrm{h})=\frac{\mathrm{MC} \text { reduction }(\%)}{\text { Drying period (hours) }}
$$

\section{Determination of the Drying Defects}

Drying defects were determined based on the characteristics of drying defects mentioned in Tenorio et al. (2012) and Listyanto et al. (2016). The five drying defects examined in this study were honeycombing, surface checks, end checks, collapse, and cupping.

\section{Data Analysis}

The effects of the pretreatments on the drying rate and defects were analyzed using one-way ANOVA and Tukey's multiple mean comparison test.

\section{RESULTS AND DISCUSSION}

\section{Moisture Content}

The mean initial moisture contents $\left(\mathrm{MC}_{\mathrm{i}}\right)$, final moisture content $\left(\mathrm{MC}_{\mathrm{f}}\right)$, and moisture loss of the quarter and rift sawn boards during the drying process for untreated and pretreated samples are shown in Tables 3 and 4 for the 7-year-old and 10-year-old $A$. mangium samples, respectively. Generally, boards from the 7-year-old wood had a higher $\mathrm{MC}_{\mathrm{i}}$ than the 10-year-old wood. Chowdhury et al. (2005) showed that the green moisture content of $A$. mangium decreased with age. It is not unusual for a fresh-cut $A$. mangium timber to have more than $100 \%$ moisture content. The green moisture content of $A$. mangium at breast height from Kukut Sabah ranged from $88 \%$ to $140 \%$ (Hon 1984). The moisture contents of standing stems of A. mangium from Malaysia, Vietnam, and the Philippines were extremely high in the sapwood and heartwood (Yamamoto et al. 2003). They recorded moisture contents of $76 \%$ to $149 \%$ and $78 \%$ to $253 \%$ in the sapwood and heartwood, respectively. A high $\mathrm{MC}_{\mathrm{i}}$ in $A$. mangium wood was also reported by Tenorio and Moya (2011) and Moya et al. (2011). The moisture content of freshly cut logs and green lumber ranges from $30 \%$ to greater than $200 \%$ (Glass and Zelinka 2021). The information about the green moisture content is important for harvesting and transportation equipment, procuring wood on a weight basis (such as in pulpwood), or transporting it in green condition.

After drying using the schedule recommended for 7-year-old (as shown in Table 1) and 10-year-old A. mangium boards (as shown in Table 2), the $\mathrm{MC}_{\mathrm{f}}$ ranged from $8 \%$ to $15 \%$. Generally, rift sawn boards have a lower moisture content than quarter sawn boards. Results also showed that a higher $\mathrm{MC}_{\mathrm{i}}$ resulted in a higher moisture loss. 
Table 3. Mean Moisture Content of the Pretreated and Untreated Quarter and Rift Sawn Boards of 7-year-old Acacia mangium Wood for the Initial, Final, and Total Moisture Loss Following Drying

\begin{tabular}{|c|c|c|c|c|c|c|c|c|}
\hline \multirow{2}{*}{ Drying phase } & \multicolumn{7}{|c|}{ Pretreatment } \\
\cline { 2 - 10 } & Untreated & \multicolumn{2}{|c|}{ Incision } & Forced air-drying & \multicolumn{2}{c|}{ Pressure } \\
\cline { 2 - 9 } & Quarter & Rift & Quarter & Rift & Quarter & Rift & Quarter & Rift \\
\hline Initial moisture & $120^{*}$ & 121 & 114 & 117 & 98 & 95 & 106 & 102 \\
content (MCi) (\%) & $(5.1)^{\star *}$ & $(6.8)$ & $(5.5)$ & $(6.5)$ & $(4.6)$ & $(3.4)$ & $(2.0)$ & $(5.8)$ \\
\hline $\begin{array}{c}\text { Final moisture } \\
\text { content (MC })(\%)\end{array}$ & 15 & 10 & 13 & 10 & 14 & 11 & 12 & 8 \\
& $(2.4)$ & $(1.0)$ & $(2.4)$ & $(1.1)$ & $(2.3)$ & $(2.4)$ & $(2.7)$ & $(0.8)$ \\
\hline Moisture loss (\%) & 105 & 112 & 101 & 108 & 84 & 84 & 94 & 94 \\
& $(3.9)$ & $(6.8)$ & $(3.4)$ & $(5.9)$ & $(4.5)$ & $(2.0)$ & $(2.0)$ & $(5.4)$ \\
\hline Note: * mean values of $\mathrm{n}=6$; and ${ }^{* *}$ values in parentheses indicate the standard error of the \\
mean
\end{tabular}

Table 4. Mean Moisture Content of the Pretreated and Untreated Quarter and Rift Sawn Boards of 10-year-old Acacia mangium Wood for the Initial, Final, and Total Moisture Loss Following Drying

\begin{tabular}{|c|c|c|c|c|c|c|c|c|}
\hline \multirow{3}{*}{ Drying phase } & \multicolumn{9}{|c|}{ Pretreatment } \\
\cline { 2 - 10 } & \multicolumn{2}{|c|}{ Untreated } & \multicolumn{2}{|c|}{ Incision } & \multicolumn{2}{c|}{ Forced air-drying } & \multicolumn{2}{c|}{ Pressure } \\
\cline { 2 - 9 } & Quarter & Rift & Quarter & Rift & Quarter & Rift & Quarter & Rift \\
\hline Initial moisture & $96^{*}$ & 104 & 101 & 109 & 96 & 86 & 114 & 99 \\
content (MCi) (\%) & $(4.1)^{\star *}$ & $(2.0)$ & $(4.0)$ & $(2.0)$ & $(4.9)$ & $(3.5)$ & $(2.2)$ & $(3.0)$ \\
\hline Final moisture & 11 & 12 & 10 & 8 & 14 & 8 & 11 & 11 \\
content (MCf) (\%) & $(1.5)$ & $(1.0)$ & $(0.9)$ & $(1.7)$ & $(2.0)$ & $(1.2)$ & $(1.7)$ & $(3.8)$ \\
\hline \multirow{2}{*}{ Moisture loss (\%) } & 85 & 91 & 92 & 101 & 82 & 79 & 102 & 88 \\
& $(3.8)$ & $(1.5)$ & $(3.9)$ & $(3.0)$ & $(4.2)$ & $(3.9)$ & $(2.0)$ & $(3.0)$ \\
\hline
\end{tabular}

Note: * mean values of $n=6$; and ${ }^{* *}$ values in parentheses indicate the standard error of the mean

\section{Wet Pockets in the Dried Wood}

After the drying, the presence of wet pockets was detected, as there was a slightly different colour in the area of the wood with a wet pocket. The area with wet pockets had a darker colour than the wood area without wet pockets. Untreated sample boards of 7year-old A. mangium developed the largest area of wet pocket, with an average of $288 \mathrm{~cm}^{2}$. The smallest wet pocket was in the pressure-treated board, with an average of $122 \mathrm{~cm}^{2}$, which was $58 \%$ less than the untreated sample boards. Incision and forced air-dry treated sample boards recorded lower average wet pocket areas by $37 \%$ and $34 \%$ compared to untreated boards, respectively. For the 10-year-old A. mangium wood, the untreated sample boards developed a larger mean wet pocket area of $380 \mathrm{~cm}^{2}$. Pressure-treated, incised, and forced air-dry boards showed a decrease in the average wet pocket areas of $73 \%, 57 \%$, and $6 \%$, respectively. This study showed that sample boards with no pretreatment tended to have a larger wet pocket area after drying. Pressure pretreatment can reduce the occurrence of wet pockets in dried A. mangium sample boards in both 7- and 10-year-old A. mangium wood. 
Wet pockets in heartwood contain huge moisture contents, which are $10 \%$ greater than the normal moisture content of the wood (Simpson 1991; Watanabe et al. 2010). The occurrence of wet pockets is high in A. mangium kiln-dried lumber, where $64 \%$ of the 216 boards had wet pockets (Tenorio and Moya 2011). In A. mangium wood, the moisture content ranged from $12 \%$ to $76 \%$, compared to $12 \%$ to $22 \%$ outside the wet pockets (Tenorio et al. 2012). The amount of wet pockets usually is high in heartwood due to the extractive contents, which block the flow of water molecules through the vessels and pits. Boards from an older age of tree are prone to wet pockets remaining after the kiln drying process due to the high percentage of heartwood, whereas wet pockets were absent in lumber with high sapwood proportions (Moya et al. 2008).

The sawing pattern of the wood also influences the distribution of the wet pockets in the wood. Generally, rift sample boards from 7- and 10-year-old A. mangium wood recorded the lowest average area of wet pockets after drying compared to quarter sample boards. The orthotropic direction of the wood can influence the occurrence of wet pockets because it affects the movement of the water from the wood (Chauhan and Aggarwal 2004).

The cell arrangement in the wood varies with the orthotropic direction of the wood (Shmulsky and Jones 2019). Quarter sawn boards have radial orthotropic direction, which tends to have low permeability; thus, it is difficult for the water in the wet pocket area to diffuse out in quarter-sawn boards (Moya and Muñoz 2008). Rift sawn boards have a combination of tangential and radial orthotropic directions. In the tangential direction, the water from the wood will move out from the wood through the ray cells; thus, the movement of water is not restricted by the blocked pits in fiber (Moya and Muñoz 2008).

Pressure-treated rift sample boards recorded the lowest average area of wet pockets compared to quarter sample boards and amongst the other pretreatments (as shown in Table 5). This might be due to the changes in the anatomical characteristics of the sample boards after pressure pretreatments. The sample boards with no pretreatment tended to produce a large area of wet pockets. Pressure pretreatment alleviated wet pockets in dried A. mangium sample boards in both 7- and 10-year-old A. mangium wood.

Table 5. Mean Wet Pockets Area After the Drying of Untreated and Pretreated 7year-old and 10-year-old Acacia mangium Quarter and Rift Sawn Boards

\begin{tabular}{|c|c|c|c|c|c|}
\hline \multirow{2}{*}{$\begin{array}{c}\text { Age of the Acacia } \\
\text { mangium Wood }\end{array}$} & \multirow{2}{*}{$\begin{array}{l}\text { Sawing } \\
\text { Pattern }\end{array}$} & \multicolumn{4}{|c|}{ Pretreatment } \\
\hline & & Untreated & Incision & Forced air-drying & Pressure \\
\hline \multirow{2}{*}{ 7-year-old boards } & Quarter & $\begin{array}{l}491^{*} b^{* * *} \\
(138)^{\star *}\end{array}$ & $\begin{array}{l}320 \mathrm{a} \\
(133)\end{array}$ & $\begin{array}{l}196 a \\
(121)\end{array}$ & $\begin{array}{c}227 \mathrm{a} \\
(99)\end{array}$ \\
\hline & Rift & $\begin{array}{c}185 \mathrm{a} \\
(89)\end{array}$ & $\begin{array}{l}39 a \\
(25)\end{array}$ & $\begin{array}{l}85 a \\
(57) \\
\end{array}$ & $\begin{array}{l}17 \mathrm{a} \\
(11)\end{array}$ \\
\hline \multirow{2}{*}{ 10-year-old boards } & Quarter & $\begin{array}{c}629 \mathrm{~b} \\
(78)\end{array}$ & $\begin{array}{l}200 \mathrm{a} \\
(108)\end{array}$ & $\begin{array}{l}432 \mathrm{a} \\
(129)\end{array}$ & $\begin{array}{c}112 \mathrm{a} \\
(78)\end{array}$ \\
\hline & Rift & $\begin{array}{l}328 \mathrm{a} \\
(185)\end{array}$ & $\begin{array}{c}130 \mathrm{a} \\
(40)\end{array}$ & $\begin{array}{l}89 a \\
(56)\end{array}$ & $\begin{array}{l}90 \mathrm{a} \\
(18)\end{array}$ \\
\hline
\end{tabular}

The ability of pressure to improve the wood permeability by providing deep penetration and retention of wood preservatives is well established (Shmulsky and Jones 
2019). In this study, the pressure was applied to improve water movement in the wood, reducing the incidence of wet pockets at the end of drying. Pressure pretreatment helped open up the connective wood passages by breaking down the pit membrane and intercellular spaces in the wood, which blocked the air passages. Pressure from steam explosions leads to micro-cracks on the inner cell walls, pits, and vessels of Norway spruce boards (Muzamal et al. 2017). Exerting high pressure to the sample boards of Chinese poplar (Populus cathayana Rehd) before drying, followed by the instantaneous release of the pressure, caused the pit membranes to fracture, thus increasing the wood permeability (Ma et al. 2015).

\section{Drying Time and Rate}

The drying times of the untreated and pretreated 7-year-old and 10-year-old $A$. mangium boards are shown in Figs. 4 and 5. The untreated 7-year-old A. mangium (Fig. 4) took $531 \mathrm{~h}$ to dry both untreated quarter sawn and incised quarter sawn boards to reach the $\mathrm{MC}_{\mathrm{f}}$ of 15 and $13 \%$, respectively. The longest time taken was $745 \mathrm{~h}$ for drying both untreated rift sawn and incised boards to attain $\mathrm{MC}_{\mathrm{f}}$ of $10 \%$ for both test samples. The pressure-treated quarter and rift sawn boards recorded the shortest drying time $(453 \mathrm{~h})$ in 7-year-old A. mangium wood.

For 7-year-old A. mangium wood, the pressure-treated sample boards had the highest drying rate (Table 6). The drying rate for the pressure pretreatments was $0.21 \%$ moisture loss per hour. The incised pretreated rift-sawn boards showed the slowest drying rate, a $0.14 \%$ moisture loss per hour. Generally, the drying rate of the rift-sawn boards in the untreated and pretreated boards was considerably faster than the quarter sawn boards.

The drying time for the 10-year-old $A$. mangium boards was the same, ranging from $454 \mathrm{~h}$ to $478 \mathrm{~h}(19 \mathrm{~d}$ to $20 \mathrm{~d})$ regardless of sawing patterns or treatment. The mean $\mathrm{MC}_{\mathrm{f}}$ of the boards ranged from $8 \%$ to $14 \%$ (Fig. 9). The pressure-treated samples recorded the highest drying rate for 10-year-old $A$. mangium wood, with a mean moisture loss per hour of $0.22 \%$ and $0.19 \%$ for quarter sawn and rift-sawn boards, respectively (as shown in Table 6). Forced air drying had the slowest drying rate, $0.17 \%$ moisture loss per hour. Pressure pretreated quarter-sawn boards showed a substantial effect on improving the drying rate for 10-year-old $A$. mangium boards. An experimental drying trial of $25 \mathrm{~mm}$-thick $A$. mangium using a drying oven took between $500 \mathrm{~h}$ and $650 \mathrm{~h}$ to accomplish a mean $\mathrm{MC}_{\mathrm{f}}$ between 4.3\% and 27.4\% (Gan and Zairul 2011b; Gan et al. 2011). Using the same thickness but a schedule with higher temperatures, a kiln drying time of $337 \mathrm{~h}$ to $337 \mathrm{~h}$ was achieved, but the $\mathrm{MC}_{\mathrm{f}}$ was greater, ranging from $9 \%$ to $52 \%$ (Tenorio and Moya 2011).

The drying rate for the boards that were pretreated with pressure was the best for both ages, especially for 7-year-old A. mangium wood. The pressure pretreatment in this study involved vacuuming air and water from the wood before applying air pressure and finally the rapid release of pressure. Vacuuming the wood samples was performed to remove air and water from the wood, especially in the cell wall of the wood, in order to create a difference in gradient between the layers of the wood. The existence of driving forces improved the rate of timber drying by creating a moisture gradient between the surface and centre of the wood (Espinoza and Bond 2016). The rapid release of pressure resulted in fractures in the pits in the wood cell, thus enlarging the water passage for better water movement (Zhang and Cai 2006). Ma et al. (2015) reported that the permeability of Populus cathayana Rehd wood increased when it was pretreated via the micro-explosion technique. Micro-explosion involves a burst of high pressure and subsequently releasing the pressure momentarily in less than $0.1 \mathrm{sec}$, resulting in a better drying rate due to the 
fracturing of the pits, thus enlarging the passages for water movement in the wood. Pressure pretreatment resulted in a better rate of moisture content diffusion, which was attributed to anatomical changes in cell walls, pits, wood fibers, and connective passages in the wood.
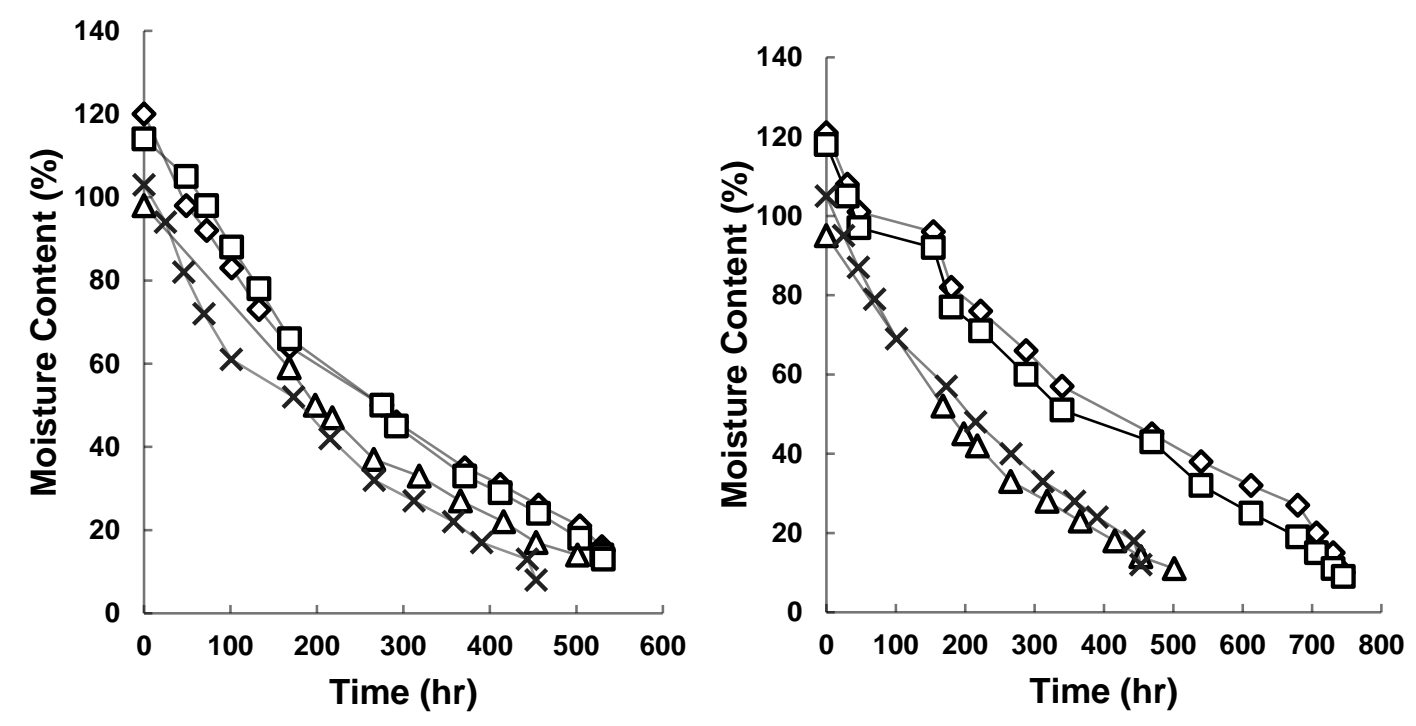

\section{$\checkmark$-Untreated $-\square-$ Incision $\Delta$-Forced air dry $\rightarrow$-Pressure}

Fig. 4. The decrease in the moisture content (\%) of the untreated and pretreated 7-year-old Acacia mangium wood: (A) quarter sawn board; and (B) rift sawn board
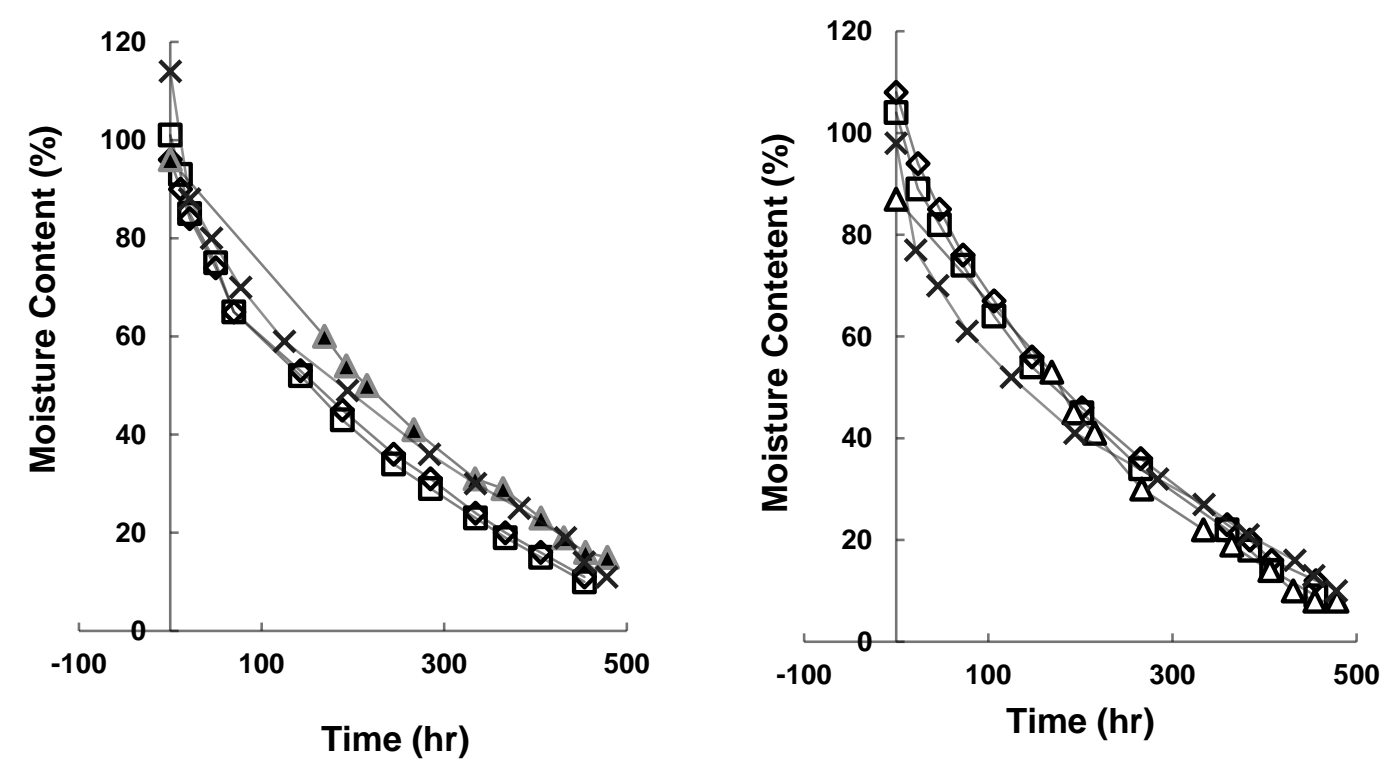

$\diamond$ - Untreated $-\square-$ Incision $-\Delta$-Forced air dry $\rightarrow$-Pressure

Fig. 5. The decrease in the moisture content (\%) of the untreated and pretreated 7-year-old Acacia mangium wood: (A) quarter sawn board; and (B) rift sawn board 
Table 6. Mean Drying Rate of the Untreated and Pretreated 7-Year-Old and 10Year-Old Acacia mangium Wood Quarter and Rift Sawn Boards

\begin{tabular}{|c|c|c|c|c|c|}
\hline \multirow{2}{*}{$\begin{array}{l}\text { Age of the Acacia } \\
\text { mangium Wood }\end{array}$} & \multirow{2}{*}{$\begin{array}{l}\text { Sawing } \\
\text { Pattern }\end{array}$} & \multicolumn{4}{|c|}{ Pretreatment } \\
\hline & & Untreated & Incision & Forced air-drying & Pressure \\
\hline \multirow{2}{*}{ 7-year-old boards } & Quarter & $\begin{array}{c}0_{0.20^{*} \mathrm{~cd}^{\star *}} \\
(0.00)^{\star *}\end{array}$ & $\begin{array}{l}0.18 \mathrm{C} \\
(0.00)\end{array}$ & $\begin{array}{c}0.17 \mathrm{bc} \\
(0.01)\end{array}$ & $\begin{array}{l}0.21 d \\
(0.00)\end{array}$ \\
\hline & Rift & $\begin{array}{c}0.15 \mathrm{ab} \\
(0.01)\end{array}$ & $\begin{array}{l}0.14 a \\
(0.00)\end{array}$ & $\begin{array}{c}0.17 \mathrm{bc} \\
(0.00)\end{array}$ & $\begin{array}{l}0.21 \mathrm{~d} \\
(0.01)\end{array}$ \\
\hline \multirow{2}{*}{ 10-year-old boards } & Quarter & $\begin{array}{c}0.20 \mathrm{bc} \\
(0.00)\end{array}$ & $\begin{array}{c}0.21 \mathrm{bc} \\
(0.01)\end{array}$ & $\begin{array}{c}0.18 \mathrm{ab} \\
(0.01)\end{array}$ & $\begin{array}{l}0.22 \mathrm{C} \\
(0.00)\end{array}$ \\
\hline & Rift & $\begin{array}{c}0.20 \mathrm{bc} \\
(0.00)\end{array}$ & $\begin{array}{l}0.22 \mathrm{c} \\
(001)\end{array}$ & $\begin{array}{l}0.17 a \\
(0.01)\end{array}$ & $\begin{array}{c}0.19 \mathrm{abc} \\
(0.00)\end{array}$ \\
\hline \multicolumn{6}{|c|}{$\begin{array}{l}\text { Note: }{ }^{*} \text { Mean values of } n=6 ;{ }^{* *} \text { Values in parentheses indicate the standard error of the } \\
\text { mean; and }{ }^{* * *} \text { Mean followed by a different letter in each age row indicates significant } \\
\text { difference at } 5 \% \text { level }\end{array}$} \\
\hline
\end{tabular}

\section{Drying Defects}

Before the drying process, the A. mangium boards showed little to no incidence of twists, cups, or checks. The drying defects were only assessed after drying in the chamber was completed. The incidences of twists, cups, checks, and splits increased with the drying process (Berrocal et al. 2017). This study showed that certain drying defects developed in all untreated and pretreated sample boards (as shown in Tables 7 and 8).

Honeycombing and surface checks only developed in untreated 7-year-old $A$. mangium wood in both the quarter and rift-sawn boards. However, no honeycombing and surface checks were found in 10-year-old A. mangium wood in all pretreated boards. Surface checks only developed in untreated and incised quarter-sawn boards from 7-yearold $A$. mangium wood. There were no end checks that occurred in the 10-year-old quarter sawn and rift sawn boards. For all the 7-year-old pretreated rift-sawn boards, no end checks were observed. However, $17 \%$ and $33 \%$ of the incised quarter-sawn and forced air dryingtreated boards developed end checks, respectively. Both untreated and incised boards were prone to collapse in both the quarter and rift-sawn boards of both A. mangium ages. Pressure-treated boards were free of collapse. Only one of the 10-years old A. mangium pressure-treated sample boards with mild collapse. Cupping was the most common drying defect developed in both ages of A. mangium wood. Even the pressure-treated boards had cupping occur.

All pretreated 27-mm thick boards developed cupping at the end of the drying period. Cupping is a common warping defect that occurs in most wood species, including A. mangium, and this is due to the inherent characteristics of the wood. According to Lim et al. (2003), A. mangium is prone to distortion and is highly refractory. Tenorio et al. (2012) indicated that $92 \%$ of the tested sample boards developed mild cupping. Warping is a common drying defect that forms after drying, especially in plantation timber, which is anticipated due to their growth stress (Lim et al. 2003).

This study showed mild defects, i.e., cupping and surface checks, occurred in boards pretreated via the forced-air drying and pressure methods. The steadiness of the flow of air in the forced-air drying method helps remove the moisture above the wood, allowing the wood moisture to evaporate without causing timber tension and stress in the wood. Accelerated air drying reduces the incidence of warp and surface checks (McMillen 
and Wengert 1977). Pre-drying before conventional drying could reduce the drying defect problem (Lim et al. 2003). In pressure pretreatment, blocked water movement is reduced due to the wood's fractured pits, cell walls, vessels, and fibres.

Table 7. Percentage of Drying Defect Incidences in 7-year-old Acacia mangium Wood Quarter and Rift Sawn Sample Boards

\begin{tabular}{|c|c|c|c|c|c|c|}
\hline $\begin{array}{c}\text { Sawing } \\
\text { Pattern }\end{array}$ & Pretreatment & Honeycombing & $\begin{array}{c}\text { Surface } \\
\text { checks }\end{array}$ & $\begin{array}{c}\text { End } \\
\text { Checks }\end{array}$ & Collapse & Cupping \\
\hline \multirow{4}{*}{ Quarter } & Untreated & $33^{*}$ & 33 & 0 & 33 & 83 \\
\cline { 2 - 7 } & Incision & 0 & 17 & 17 & 17 & 100 \\
\cline { 2 - 7 } & $\begin{array}{c}\text { Forced air } \\
\text { dry }\end{array}$ & 0 & 0 & 33 & 17 & 17 \\
\cline { 2 - 7 } & \begin{tabular}{c} 
Pressure \\
\multirow{4}{*}{ Rift }
\end{tabular} & 0 & 0 & 0 & 0 & 33 \\
\cline { 2 - 7 } & $\begin{array}{c}\text { Untreated } \\
\text { Incision }\end{array}$ & 17 & 0 & 0 & 50 & 76 \\
\cline { 2 - 7 } & $\begin{array}{c}\text { Forced air } \\
\text { dry }\end{array}$ & 0 & 0 & 0 & 50 & 100 \\
\cline { 2 - 7 } & \begin{tabular}{c} 
Pressure \\
\hline
\end{tabular} & 0 & 0 & 0 & 0 & 50 \\
\hline
\end{tabular}

Table 8. Percentage of Drying Defect Incidences in 10-year-old Acacia mangium Wood Quarter and Rift Sawn Sample Boards

\begin{tabular}{|c|c|c|c|c|c|c|}
\hline $\begin{array}{l}\text { Sawing } \\
\text { Pattern }\end{array}$ & Pretreatment & Honeycombing & $\begin{array}{l}\text { Surface } \\
\text { checks }\end{array}$ & $\begin{array}{l}\text { End } \\
\text { Checks }\end{array}$ & Collapse & Cupping \\
\hline \multirow{4}{*}{ Quarter } & Untreated & $0^{*}$ & 0 & 0 & 17 & 100 \\
\hline & Incision & 0 & 0 & 0 & 67 & 83 \\
\hline & $\begin{array}{l}\text { Forced air } \\
\text { dry }\end{array}$ & 0 & 0 & 0 & 33 & 50 \\
\hline & Pressure & 0 & 0 & 0 & 17 & 83 \\
\hline \multirow{4}{*}{ Rift } & Untreated & 0 & 0 & 0 & 33 & 83 \\
\hline & Incision & 0 & 0 & 0 & 67 & 17 \\
\hline & $\begin{array}{l}\text { Forced air } \\
\text { dry }\end{array}$ & 0 & 0 & 0 & 0 & 67 \\
\hline & Pressure & 0 & 0 & 0 & 0 & 67 \\
\hline
\end{tabular}

The 7-year-old A. mangium wood was more prone to drying defects than the 10year-old wood, regardless of pretreatments, probably due to a greater amount of juvenile wood in the younger A. mangium wood. Chowdhury et al. (2005) reported that the tangential shrinkage of 10 -year-old $A$. mangium wood was considerably greater than the 
15- and 20-year-old wood. The increase in twist, cup, check, and split defects of Tectona grandis boards was related to the juvenile wood presence (Berrocal et al. 2017). Juvenile wood is known for dimensional instability in dried lumber due to its higher longitudinal shrinkage than normal wood (Zobel and Sprague 2012).

Among the pretreatments, the pressure and forced-air drying methods showed promising results for 7- and 10-year-old A. mangium wood in terms of minimizing drying defects. None of the pressure and forced-air drying pretreated boards developed severe drying defects. This may be due to the anatomical changes created by the pretreatments, allowing the water in the wood to diffuse out from the wood without force; thus, less stress developed in the wood during drying. According to Tenorio et al. (2012) drying defects are not affected by drying schedules but by climate, grain pattern, and the initial and final moisture contents.

\section{CONCLUSIONS}

1. Pressure pretreatment improved the drying parameters of $A$. mangium boards. The total area of wet pockets was reduced, and a higher rate of drying was obtained. In addition, the boards were defect-free with only mild collapse.

2. Incision pretreatment yielded a good drying rate in older A. mangium wood; however, it could not alleviate the presence of wet pockets. The boards tended to collapse at the end of the drying process.

3. Forced air drying has the lowest drying rate but was unable to reduce the occurrence of wet pockets as well as pressure pretreatment.

4. Generally, pretreatments provided a better quality of dried boards than untreated ones. This suggests that $A$. mangium wood requires pretreatment before drying.

5. Younger A. mangium wood appeared most likely to develop greater drying defects than older wood.

\section{ACKNOWLEDGMENTS}

The authors are thankful to the Sarawak Timber Association and the Sarawak Timber Industry Development Cooperation for the scholarship award of the Forestry Nichement. The authors are also grateful to Syarikat Samling Timber Sdn Bhd for providing the raw materials and assistance for the study. In addition, the authors are extremely grateful to the Applied Forest Science and Industry Development (AFSID), Sarawak Forestry Corporation, for providing technical support and facilities. The Ministry of Higher Education Malaysia supported this study under the Fundamental Research Grant Scheme FRGS/1/2017/WAB07/UNIMAS/02/1. 


\section{REFERENCES CITED}

Ananías, R.A., Sepúlveda-Villarroel, V., Pérez-Peña, N., Torres-Mella, J., SalvoSepúlveda, L., Castillo-Ulloa, D., and Salinas-Lira, C. (2020). "Radio frequency vacuum drying of Eucalyptus nitens juvenile wood," BioResources 15(13), 48864897. DOI: 10.15376.biores/15.3.4886-4897

ASTM D4442-16 (2016). "Standard test method for direct moisture content measurements of wood and wood-based materials," ASTM International, West Conshohocken, PA.

Berrocal, A., Moya, R., Rodríquez-Solis, A. M., and Muñoz, F. (2017). "Drying of plantation-grown Tectona grandis wood with daily-controlled drying rate schedule," Journal of Tropical Forest Science 29(1), 69-79.

Chai, H., Xu, C. Li, J., Kong, F., and Cai, Y. (2019). "Effects of pretreatment with saturated wet air and steaming on the high-frequency vacuum drying characteristics of wood," BioResources 14(4), 9601-9610. DOI: 10.15376/biores.14.4.9601-9610

Chauhan, S. S, and Aggarwal, P. (2004). "Effect of moisture sorption state on transverse dimensional change in wood," Holz als Roh- und Werkstoff 62, 50-55. DOI: 10.1007/s00107-003-0437-y

Chowdhury, M. Q., Shams. M. I., and Alam, M. (2005). "Effects of age and height variation on physical properties of mangium (Acacia mangium Willd.) wood," Australian Forestry 68(1), 17-19. DOI: 10.1080/00049158.2005.10676221

Dashti, H., Shahverdi, M. Taghiyari, H. R., Salehpur, S., and Heshmati, S. (2012). "Effects of steaming and microwave pretreatments on mass transfer characteristics of Aleppe oak (Quercus infectoria)," BioResources 7(3), 3262-3273. DOI: 10.15376/biores.7.3.3262-3273

Elustondo, D. M., Oliveira. L., and Avramidis, S. (2010). "New methodology to optimize sorting in wood drying," Maderas, Ciencia Y Tecnologia 12(2), 79-91. DOI 10.4067/S0718-221X2010000200003

Espinoza, O., and Bond, B. (2016). "Vacuum drying of wood - State of the art," Current Forestry Report 2, 223-235. DOI: 10.1007/s40725-016-0045-9

Gan, K. S., Tan, J. L., and Zairul, A. R. (2011). "Drying characteristic of tropical plantation-grown timber using the proposed testing methods," in: Proceedings of the Seminar and Workshop on Improved Utilization of Tropical Plantation Timbers, 2325 March, Kula Lumpur, Malaysia, pp. 107-113.

Gan, K. S., and Zairul, A .R. (2011b). "Kiln drying of Acacia mangium planks pretreated in hot water," in: Properties of Acacia mangium Planted Peninsular Malaysia, S. C. Lim, K. S. Gan, Y. E. Tan (ed.), Forest Research Institute Malaysia, Kepong, Malaysia, 83-86.

Gan, K. S., and Zairul, A. R. (2011a). "Drying characteristics using the standard test methods," in: Properties of Acacia mangium Planted Peninsular Malaysia, S. C. Lim, K. S. Gan, Y. E. Tan (ed.), Forest Research Institute Malaysia, Kepong, Malaysia, pp. 74-82.

Gan, K. S., Zairul, A. R., and Tan, J. L. (2015). "Effectiveness of pretreatments on Acacia mangium for conventional steam-heated kiln drying," Journal of Tropical Forest Science 27(1), 127-135.

Glass, S. V., and Zelinka, S. L. (2021). "Chapter 4: Moisture relations and physical properties of wood," in: Wood Handbook - Wood as an Engineering Material, U.S. Department of Agriculture Forest Products Laboratory, Madison, WI. 
Günzerodt, H., Walker, J. C. F., and Whybrew, K. (1986). "Compression rolling and hot water soaking: Effect on the drying and treatability of Nothofagus fusca heartwood," New Zealand Journal of Forestry Science 16(2), 223-236.

Hon, C. H. (1984). "Graded sawn timber recovery study of Acacia mangium," Malaysian Forester 47(1-2), 116-124.

Lim, K. C., Gan, K. S., and Choo, K. T. (2003). "The characteristics, properties and uses of plantation timbers- rubberwood and Acacia mangium," Timber Technology Bulletin 26, 1-11.

Listyanto, T., Darmawan, Y. S., Pujiarti, R., Hidayati,F., Lukmandaru, G., and Sulistyo, J. (2016). "Development of drying schedule of superior and conventional teak wood of 10-years old planted in Blora, Central Jaya," Jurnal Ilmu Kehutanan 10(1), 65-73. DOI: $10.22146 /$ jik.12633

Ma, Q., Zhao, Z., Wang, T., and Yi, S. (2015). "Effects of moisture on drying rate of micro-explosion pretreated fast-growing poplar wood," Journal of Wood Research 60(6), 899-906.

McMillen, J. M., and Wengert, E. M. (1977). Drying Eastern Hardwood Lumber (Agriculture Handbook No. 528), U.S. Department of Agriculture Forest Products Laboratory, Madison, WI.

Moya, R. R., and Muñoz, F. A. (2008). "Wet pockets in kiln dried Gmelina arborea lumber," Journal of Tropical Forest Science 20(1), 48-56.

Moya, R., Tovar, D. A., Tenorio, C., and Bond, B. (2011). "Moisture content variation in kiln-dried lumber from plantations of Vochysia guatemalensis," Wood and Fiber Science 43(2), 121-129.

Muzamal, M., Gamstedt, E. K., and Rasmuson, A. (2017). "Mechanistic study of microstructural deformation and stress in steam-exploded softwood," Wood Science Technology 51, 447-462. DOI: 10.1007/s00226-017-0896-7

Shmulsky, R., and Jones, P. D. (2019). Forest Products and Wood Science: An introduction, Seventh Edition, John Wiley \& Sons, Inc., Hoboken, NJ.

Simpson, W. T. (1991). Dry Kiln Operator's Manual (Agriculture Handbook No. 118), U.S. Department of Agriculture Forest Products Laboratory, Madison, WI.

Tan, J. L. (2015). "Drying characteristics," in: Proceedings of the SFC/STA Research Seminar on Basic and Working Properties of Acacia mangium Planted in Sarawak, Kuching, Sarawak, Malaysia, pp. 69-86.

Tenorio, C., and Moya, R. (2011). "Kiln drying of Acacia mangium Willd: Consideration of moisture content before and after drying and presence of wet pocket," Drying Technology Journal 29(15), 1845-1854. DOI: 10.1080/07373937.2011.610912

Tenorio, C., Moya, R., and Quessada-Pineda, H. J. (2012). "Kiln drying of Acacia mangium wood: Colour, shrinkage, warp, split and check in dried lumber," Journal of Tropical Forest Science 24(1), 125-139.

Watanabe, K., Hart, F., Mansfield, S. D., and Avramidis, S. (2010). "Detection of wet pockets on the surface of Tsuga heterophylla (Raf) Sarg. by near infrared (NIR) spectroscopy," Holzforschung 64(1), 55-60. DOI: 10.1515/HF.2010.014

Weng, X., Zhou, Y., Fu, Z., Gao, X., Zhou, F., and Jiang, J. (2021). "Effects of microwave pretreatment on drying of $50 \mathrm{~mm}$-thickness Chinese fir lumber," Journal of Wood Science 67, 13. DOI: 10.1186/s10086-021-01942-2

Yamamoto, K., Sulaiman, O., Kitingan, C., Choon. L. W., and Nhan, N. T. (2003). "Moisture distribution in stems of Acacia mangium, A. auriculiformis and hybrid acacia trees," Japan Agricultural Research Quarterly 37(3), 207-212. DOI: 
10.6090/jarq.37.207

Yang, L. and Liu, H. (2018). "A review of eucalyptus wood collapse and its control," BioResources 13(1), 2171-2181. DOI:10.15376/biores.13.1.Yang

Zhang, Y., and Cai, L. (2006). "Effects of steam explosion on wood appearance and structure of sub-alpine fir," Wood Science and Technology 40(5), 427-436. DOI: 10.1007/s00226-005-0053-6

Zhao, Y. Wang, Z., Iida, I., Huang, R., Lu, J., and Jiang, J. (2015). “Studies on pretreatment by compression for wood drying I: Effects of compression ratio, compression direction and compression speed on the reduction of moisture content in wood," Journal of Wood Science 61, 113-119. DOI 10.1007/s10086-014-1451-x

Zobel, B. J., and Sprague, J. R. (2012). Juvenile Wood in Forest Trees, Springer Science $\&$ Business Media, Berlin/Heidelberg, Germany.

Article submitted: October 25, 2021; Peer review completed: December 11, 2021;

Revised version received and accepted: January 11, 2022; Published: January 19, 2022.

DOI: 10.15376/biores.17.1.1643-1658 